\title{
New batteries needed for design of US space telescope?
}

\section{San Francisco}

Project managers for the Hubble Space Telescope are faced with the tough decision of whether to try to design, test and install an entirely new set of batteries before the planned launch late next year. The tight budget of NASA (the National Aeronautics and Space Administration) is one problem, the shortage of time another -but the launch date may slip.

Bertram R. Bulkin, director of scientific space programmes for Lockheed Missiles and Space Co. in Sunnyvale, California, where the 13-metre-long instrument is stored, estimates that the fix will cost about $\$ 12$ million. But the money might be well spent because the present batteries may not be up to the job.

Ever since engineers ran the telescope through a simulated "thermal vacuum" test last summer, they have fretted over the discovery that the telescope uses more power than expected, chiefly by the heaters which keep the five scientific in- struments at operating temperature. They estimate that the telescope would be idle up to 20 per cent of the time while its solar panels recharge the batteries.

"The bird is just plain colder than we thought", said Fred Wojtalik, project deputy manager at NASA's Marshall Space Flight Center in Huntsville, Alabama. The telescope and its 2.4-m mirror was to have gone into a $600-\mathrm{km}$ orbit last October with six nickelcadmium batteries. Each has a capacity of 60 ampere-hours, and must go through 16 charge-discharge cycles a day. NiCd batteries lose 40 per cent or more of their capacity under these conditions after two or three years, making periodic replacement necessary. The new heating problem means even earlier maintenance by the space shuttle.

The project leaders are reluctantly willing to fly with the present batteries, but have embarked on a crash study of nickel hydrogen batteries - pressurized devices

\section{US university presidents fight shy of pork-barrel politics}

\section{Washington}

FACED with ageing facilities and decreasing federal support for their replacement, should research universities make individual requests directly to Congress for new buildings and equipment? In the past few budget cycles, several institutions have sought so to bypass the federal agencies ostensibly qualified to make merit judgements on such requests. The issue dominated the annual meeting last week of the American Association of Universities (AAU), and will be hotly debated this year, especially when Congress starts doling out money for 1988 .

A new report, written by a committee chaired by Donald Langenberg, of the University of Illinois at Chicago, concludes that if Congress begins routinely to give money directly to institutions, it could "cause fundamental changes and damage to the research enterprise". The report argues that Congress does not fully appreciate the need for peer or merit review, and that some of its members regard the system as a merely an "old-boy" network to preserve the scientific status quo.

Funds earmarked for a particular university are often part of the pork-barrel politics by which individual members of Congress win rewards for their constituents. Representatives can win support for facilities which, although small on the scale of the federal government's support for science, may be a welcome windfall for the recipient institution. The tempting possibility of easy research money has prompted many universities to hire Washington lobbyists.

The Langenberg report recommends that Congress and universities should find a compromise between political realities and strict adherence to merit review. One partial solution would be a competitive research facilities programme, as already proposed in Congress by Representative Robert Roe (Democrat, New Jersey), chairman of the House of Representatives Science, Space and Technology Committee. AAU supports the Roe bill.

But some believe, with Cornell University president Frank Rhodes, that any divergence from peer-review will lead to chaos. In December 1985, Rhodes turned down a \$10-million Defense Department grant for a new computer because it had not been subjected to peer-review. Cornell never received the money, and Rhodes must now worry that he may have damaged Cornell's chances of receiving Defense Department money in future.

The issue of earmarking is so divisive that even the Langenberg committee members could not reach a consensus. In a dissenting addendum to the report, Arthur Sussman of the University of Chicago argues that willingness to accept even a modified form of earmarkng would be "detrimental to the long-term interests of higher education".
Joseph Palca operating much like fuel cells - which are standard equipment for many satellites in geosynchronous orbit, but which have never had to survive the rapid chargedischarge cycles of low-orbiting satellites passing through the Earth's shadow many times a day. They offer high output and a remarkable resistance to degradation. "They seem to get better with time", Bulkin says, and they should "last a good five years with no loss in capacity".

Nickel-hydrogen batteries could accommodate twice the peak power demand of the present batteries, allowing more instruments to run, or more frequent shifts in attitude by the observatory. The longer total life of the batteries could also obviate the need for one or two space shuttle maintenance missions.

If there are funds and if tests show that the new batteries would function properly, "then we are going to go for them", says Wojtalik. At the very least, the engineers plan to modify the NiCd battery-pack mounting points so that, even after the telescope is in orbit, astronauts could remove the old batteries and replace them with nickel hydrogen units. Charles Petit

\section{Superconductor rising high in Japan}

Tokyo

A conjuring trick? - no, another example of the breathtaking speed at which the Japanese are developing high-temperature superconducting ceramics.

This demonstration of levitation by Mitsubishi Electric Corporation was performed by releasing a disk of bariumyttrium-copper oxide $4 \mathrm{~cm}$ in diameter $(8 \mathrm{~g}$ weight) over a permanent magnet immediately after dunking the ceramic disk

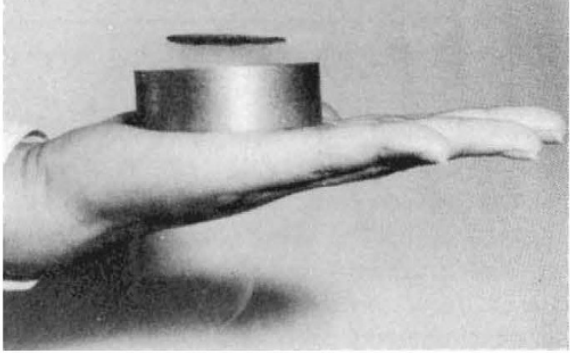

A floating ring of high-temperature superconducting ceramic.

in liquid nitrogen. A current induced in the disk by the Meissner effect set up an opposing magnetic field on which the disk 'floated' above the magnet. Mitsubishi Electric claims a current of about $40 \mathrm{~A}$ was induced in the disk - equivalent to a current density of about $200 \mathrm{~A} \mathrm{~cm}^{-2}$, nearly two orders of magnitude larger than that reported last week by Toshiba Corporation of Japan for high-temperature superconducting ceramic wire (see Nature 326, $533 ; 1987)$. 